\title{
Pelagic larval duration, growth rate, and population genetic structure of the tidepool snake moray Uropterygius micropterus around the southern Ryukyu Islands, Taiwan, and the central Philippines
}

Wen-Chien Huang ${ }^{1,2}$, Jui-Tsung Chang ${ }^{3}{ }$, Chun Liao ${ }^{3}$, Atsushi Tawa ${ }^{4}$, Yoshiyuki Iizuka ${ }^{5}$, Te-Yu Liao ${ }^{\text {Corresp.., }}{ }^{2}$, Jen-Chieh Shiao ${ }^{\text {Corresp. } 1}$

1 Institute of Oceanography, National Taiwan University, Taipei, Taiwan

2 Department of Oceanography, National Sun Yat-Sen University, Kaohsiung, Taiwan

3 Institute of Bioinformatics and Structural Biology, National Tsing Hua University, Hsinchu, Taiwan

4 National Research Institute of Far Seas Fisheries, Japan Fisheries Research and Education Agency, Orido, Shimizu, Shizuoka, Japan

5 Institute of Earth Sciences, Academia Sinica, Taipei, Taiwan

Corresponding Authors: Te-Yu Liao, Jen-Chieh Shiao

Email address: swp0117@gmail.com, jcshiao@ntu.edu.tw

The relationships between pelagic larval duration (PLD) and geographic distribution patterns or population genetic structures of fishes remain obscure and highly variable among species. To further understand the early life history of the tidepool snake moray Uropterygius micropterus and the potential relationship between PLD and population genetic structure of this species, otolith microstructure and population genetics based on concatenated mtDNA sequence (cytochrome $b$ and cytochrome oxidase subunit I, 1,336 bp) were analyzed for 195 specimens collected from eight locations around the southern Ryukyu Islands, Taiwan, and the central Philippines. Eels with longer PLD and lower otolith growth rates were observed at relatively higher latitudes with lower water temperatures (54.6 \pm 7.7 days and $1.28 \pm 0.16 \mu$ day $^{-1}$ on Ishigaki Island, Japan, vs. $43.9 \pm 4.9$ days and $1.60 \pm 0.19 \mu \mathrm{m}$ day $^{-1}$ on Badian, the Philippines), suggesting that leptocephali grew faster and had shortened pelagic periods in warmer waters. Meanwhile, the eels along the southwest coast of Taiwan had relatively longer PLD (57.9 \pm 10.5 days), which might be associated with the more complex ocean current systems compared to their counterparts collected along the east coast of Taiwan (52.6 \pm 8.0 days). However, the southwestern and eastern Taiwan groups had similar otolith growth rates $\left(1.33 \pm 0.19 \mu \mathrm{m}\right.$ day $^{-1}$ vs. $1.36 \pm$ $\left.0.16 \mu \mathrm{m} \mathrm{day}^{-1}\right)$. Despite the intergroup variation in PLD, genetic analysis revealed fluent gene flow among the tidepool snake morays in the study regions, implying that intraspecies PLD variation had a weak effect on genetic structure. The leptocephalus stage might have ensured the widespread gene flow among the study areas and leptocephalus growth was likely influenced by regional water temperature. 
1 Pelagic larval duration, growth rate, and population genetic structure of the

2 tidepool snake moray Uropterygius micropterus around the southern Ryukyu

5 Wen-Chien Huang ${ }^{1,2}$, Jui-Tsung Chang ${ }^{3}$, Chun Liao $^{3}$, Atsushi Tawa ${ }^{4}$, Yoshiyuki Iizuka ${ }^{5}$, Te-Yu

$6 \mathrm{Liao}^{2, *}$, and Jen-Chieh Shiao ${ }^{1, *}$

7

$8{ }^{1}$ Institute of Oceanography, National Taiwan University, No. 1, Sec. 4, Roosevelt Rd., Taipei 106, Taiwan

$9 \quad{ }^{2}$ Department of Oceanography, National Sun Yat-sen University, No. 70, Lienhai Rd., Kaohsiung 804, Taiwan

$10{ }^{3}$ Institute of Bioinformatics and Structural Biology, National Tsing Hua University, No. 101, Sec. 2, Kuang Fu Rd.,

11 Hsinchu 300, Taiwan

$12{ }^{4}$ National Research Institute of Far Seas Fisheries, Japan Fisheries Research and Education Agency, Orido,

13 Shimizu, Shizuoka 424-8633, Japan

$14{ }^{5}$ Institute of Earth Sciences, Academia Sinica, No. 128, Sec. 2, Academic Rd., Nankang, Taipei 115, Taiwan 15

$16 *$ Corresponding authors:

17 Jen-Chieh Shiao, e-mail: jcshiao@ntu.edu.tw; tel: 886-2-33663227; fax: 886-2-33663744

18 Te-Yu Liao, e-mail: swp0117@gmail.com; tel: 886-7-5252000\#5107; fax: 886-7-5255130 


\section{ABSTRACT}

20

21

22

23

24 25

The relationships between pelagic larval duration (PLD) and geographic distribution

patterns or population genetic structures of fishes remain obscure and highly variable among species. To further understand the early life history of the tidepool snake moray Uropterygius micropterus and the potential relationship between PLD and population genetic structure of this species, otolith microstructure and population genetics based on concatenated mtDNA sequence (cytochrome $b$ and cytochrome oxidase subunit I, 1,336 bp) were analyzed for 195 specimens collected from eight locations around the southern Ryukyu Islands, Taiwan, and the central Philippines. Eels with longer PLD and lower otolith growth rates were observed at relatively higher latitudes with lower water temperatures $\left(54.6 \pm 7.7\right.$ days and $1.28 \pm 0.16 \mu \mathrm{m}$ day $^{-1}$ on Ishigaki Island, Japan, vs. $43.9 \pm 4.9$ days and $1.60 \pm 0.19 \mu \mathrm{m} \mathrm{day}^{-1}$ on Badian, the Philippines), suggesting that leptocephali grew faster and had shortened pelagic periods in warmer waters. Meanwhile, the eels along the southwest coast of Taiwan had relatively longer PLD (57.9 \pm 10.5 days), which might be associated with the more complex ocean current systems compared to their counterparts collected along the east coast of Taiwan (52.6 \pm 8.0 days). However, the southwestern and eastern Taiwan groups had similar otolith growth rates $\left(1.33 \pm 0.19 \mu \mathrm{m} \mathrm{day}^{-1}\right.$ vs. $\left.1.36 \pm 0.16 \mu \mathrm{m}^{-1} \mathrm{day}^{-1}\right)$. Despite the intergroup variation in PLD, genetic analysis revealed fluent gene flow among the tidepool snake morays in the study regions, implying that intraspecies PLD variation had a weak effect on genetic structure. The leptocephalus stage might have ensured the widespread gene flow among the study areas and leptocephalus growth was likely influenced by regional water temperature. 
The population structure of fishes with pelagic larvae is influenced by biological and

43

44

45

46

47

48

49

50

51

52

53

54

55

56

57 58 for many fish.

59

60

61

62

63

environmental factors (Leis et al., 2013; Nanninga et al., 2014). However, many of these factors are difficult to parameterize (Nanninga et al., 2014) and pelagic larval duration (PLD) is used as a direct predictor of dispersal potential and population connectivity, especially for site-attached coral reef fishes that do not display migratory behaviors during their juvenile and adult stages (Bowen et al., 2006; Macpherson \& Raventos, 2006). Although PLD has been found to strongly influence population genetic structure only in extreme cases with very short or very long PLD (Thresher et al., 1989; Bowen et al., 2001; Weersing \& Toonen, 2009), some studies have still suggested that PLD may be a strong determinant for evaluating larval dispersal and population connectivity (e.g., Faurby \& Barber, 2012). Variation in PLD may be affected by numerous factors at inter- and intraspecific levels, including genotypes (Tsukamoto et al., 2002), physiological conditions of larvae (Reveillac et al., 2008; Han et al., 2010) and environmental changes (Searcy \& Sponaugle, 2000; Sponaugle \& Pinkard, 2004; Bergenius et al., 2005). Therefore, larval fishes that experience different environmental conditions could have varied early life history traits, leading to specific PLDs among populations (Bay et al., 2006). However, the effects of variable PLDs on population genetics remain unclear and infrequently evaluated

9 Most true eels (Anguilliformes) are demersal fish with limited migration during the juvenile to adult stages (Bassett \& Montgomery, 2011; Correia et al., 2012), except for temperate anguillids and some congrids that have offshore spawning areas (Tsukamoto, 2006; Kurogi et al., 2012). The long pelagic larval stage of leptocephalus may play an important role in their distribution and population genetic structures (Miller \& McCleave, 2007; Kuroki et al., 2009; 
64 Reece et al., 2011). Moreover, variations in the intraspecific PLD of anguillids have been

65 observed within and among geographic regions without genetic divergence. These variations in

66 PLD are likely influenced by nutrition status among individuals (Reveillac et al., 2008; Han et

67 al., 2010). Few studies have been conducted on intraspecific variation in PLDs in marine eels.

68 Kimura et al. (2004) found various PLDs and growth rates for Conger myriaster leptocephali

69 along the east coast of central Japan. Despite the various PLDs, C. myriaster breed in specific

70 spawning areas (Kurogi et al., 2012), which may counteract the influence of PLD variation on

71 their genetic structure. For other marine eel taxa with near-shore spawning strategies, the

72 correlations between variable PLD and genetic structure among geographic areas have yet to be

73 explored thoroughly.

74 The family Muraenidae, known as moray eels, is the second largest family after the

75 Ophichthidae in the Anguilliformes, with approximately 200 species in 15 genera and two

76 subfamilies (Smith, 2012). Moray eels are broadly distributed in tropical and temperate oceans.

77 Most muraenids inhabit rocky ledges and coral reefs from the intertidal zone to depths of over

$78300 \mathrm{~m}$, and some species are occasionally found in sandy or freshwater habitats (Tsukamoto et

79 al., 2014). Moray eels have high fidelity to their habitats (Bassett \& Montgomery, 2011) and

80 spawn without migrations (Moyer \& Zaiser, 1982). Therefore, moray eels are solely dispersed in

81 the pelagic leptocephalus stage, providing an effective means of evaluating the effects of PLD on

82 genetic divergence for marine eels with a local spawning strategy. For example, the tidepool

83 snake moray Uropterygius micropterus (Bleeker 1852) usually resides in the rocky intertidal

84 zone at depths shallower than $3 \mathrm{~m}$ (Chen, 1997), leading to fragmented habitat use across the

85 Indo-Pacific oceans from East Africa to Samoa, north to southern Japan, and south to

86 Australia (Froese \& Pauly, 2016). Uropterygius micropterus is a small species measuring less

87 than $40 \mathrm{~cm}$ in length (Loh et al., 2011) that has a local spawning strategy. Uropterygius 
88 89

micropterus were observed to reproduce in the rocky intertidal zone of Taitung, Taiwan during summer. Numerous males followed and entwined with a female, snapping at the female's head and trunk. Afterward, a cloud of sperm and transparent, buoyant eggs were discharged into the water (Chen, H.M., unpublished data). Due to its small size, local spawning strategy, and specific habitat use, U. micropterus would be a favorable candidate for evaluating larval dispersal and its effects on genetic structure. The present study aimed to (1) examine the otolith microstructure of $U$. micropterus to evaluate variation in PLD among sampling sites and (2) to test the relationship of differences in PLD to genetic structure.

\section{MATERIALS AND METHODS}

\section{SAMPLE COLLECTION}

One hundred and ninety-five juvenile and adult $U$. micropterus were collected by dip net and hand-lining at rocky intertidal zones along Ishigaki Island, Japan $(\mathrm{n}=14)$, six Taiwanese sites $(\mathrm{n}=142)$, and Badian, the Philippines $(\mathrm{n}=39)$ during 2014-2016 (Table 1; Fig. 1).

Shitiping $(\mathrm{n}=36)$, Jihui $(\mathrm{n}=32)$, and Green Island $(\mathrm{n}=20)$ are located on the east coast of Taiwan and are influenced by the strong, constant Kuroshio Current that flows northward yearround. Checheng $(n=31)$, Wanlitong $(n=11)$, and Liuqiu $(n=12)$ are located on the southwest coast of Taiwan, in a more complex ocean environment that is affected by numerous water masses on a seasonal basis (Shaw, 1991; Farris \& Wimbush, 1996; Hu et al., 2010). Ishigaki is also affected by the Kuroshio Current, and Badian is a relatively closed environment located on Cebu in the central Philippines.

\section{OTOLITH PREPARATION AND ANALYSIS}

Left sagittal otoliths were extracted under stereo microscope, cleaned with deionized water, dried at $55^{\circ} \mathrm{C}$ overnight, embedded in Epofix resin, and fixed on microscope slides. The 
111 prepared otoliths were grounded along the sagittal plane with 2000 and 2400 grit sandpapers

112 until the core was revealed on the surface, and then polished until smooth with $0.05 \mu \mathrm{m}$ alumina

113 powder. The ground otoliths were photographed and the growth increments were counted under

114 a compound light microscope (BX-51 Olympus, Japan) from the first feeding check (FFC) to the

115 growth check (GC) (Fig. 2). The otolith growth increments during the leptocephalus stage of $U$.

116 micropterus were distinguishable and the narrowest rings (approx. $1 \mu \mathrm{m}$ ) were larger than the

117 resolution limitation of the compound light microscope. The GC was defined by Ling et al.

118 (2005) as the prominent check at which the growth increments change from a circular to a

119 radiating pattern, accompanied by a lowered $\mathrm{Sr} / \mathrm{Ca}$ ratio. This prominent check has been

120 assumed to be associated with the beginning of metamorphosis in leptocephalus and has been

121 used in several studies of marine eel species (Ling et al., 2005; Lee et al., 2008). Otolith growth

122 increments from the first feeding ring to the $\mathrm{GC}$ were expressed as $\mathrm{T}_{\mathrm{GC}}$ (i.e., PLD). Meanwhile,

123 the radius of $\mathrm{GC}$ was measured along the longest axis and divided by $\mathrm{T}_{\mathrm{GC}}$ to calculate the mean

124 otolith growth rate $\left(\mu \mathrm{m}\right.$ increment ${ }^{-1}$, as $\left.\mathrm{G}_{\mathrm{GC}}\right)$. Some sub-increments between the wide increments

125 before GC could be ignored, and the blurred rings before FFC were excluded from the count,

126 which may have led to a slight underestimation of the actual number of increments. Fourteen

127 otoliths were randomly chosen for the $\mathrm{Sr} / \mathrm{Ca}$ ratio analysis to assist in the judgment of GC.

128 Polished otoliths were coated with a layer of carbon and analyzed by an electron probe

129 microanalyzer (EPMA, JEOL JXA-8900R). The Sr/Ca ratios were measured from the core to the

130 edge of each otolith under electron beam conditions of $15 \mathrm{kV}$ and $3 \mathrm{nA}$, beam size $5 \times 4 \mu \mathrm{m}$, and

$13110 \mu \mathrm{m}$ of spot intervals. Since the otolith growth increments of anguillid species are typically

132 deposited daily in the early leptocephalus and glass eel stages (Sugeha et al., 2001; Shinoda et

133 al., 2004), the otolith increments counted in this study were assumed to be deposited daily (i.e.,

$134 \mathrm{~T}_{\mathrm{GC}}=$ days and $\mathrm{G}_{\mathrm{GC}}=\mu \mathrm{m}$ day $^{-1}$ ). 
The daily ages and otolith growth rates of U. micropterus at different latitudes were divided

136 into three groups (Ishigaki, Taiwan, and Badian) for statistical analysis. The Taiwanese sampling

137 sites were additionally divided into eastern and southwestern groups, representing different

138 oceanic current conditions at similar latitudes, to test whether ocean currents affected the early

139 life characteristics of U. micropterus despite the small geographic scale. The statistical

140 differences in daily ages and mean daily otolith growth rates between groups were tested by

141 analysis of variance (ANOVA) and the post hoc Tukey HSD test in R (R Development Core

142 Team, 2013). The mean increment widths of sagittal otoliths for intervals of every three rings

143 were also estimated in ImageJ (Abràmoff et al., 2004) along the longest axis. The percentages of

144 daily ages for five-day intervals are shown in bar charts.

\section{POPULATION GENETIC ANALYSIS}

146 DNA was extracted from muscle tissue using a Qiagen DNA extraction kit (Qiagen, Hilden,

147 Germany) following the manufacturer's protocols. Polymerase chain reactions (PCRs) were run

148 in a total volume of $50 \mu \mathrm{L}$, including $6 \mu \mathrm{L}$ of TaKaRa (www.clontech.com) $10 \times$ buffer, $4 \mu \mathrm{L}$ of

$1492.5 \mathrm{mM}$ dNTPs, $4 \mu \mathrm{L}$ of $10 \mu \mathrm{M}$ of each primer, $0.25 \mu \mathrm{L}$ of TaKaRa Ex Taq DNA polymerase, 6

$150 \mu \mathrm{L}$ of template DNA at $50 \mathrm{ng} / \mu \mathrm{L}$, and $25.75 \mu \mathrm{L}$ of deionized water. The fragments of

151 cytochrome $b$ (cyt $b$ ) 680-bp and cytochrome oxidase subunit I (COI) 656-bp were respectively

152 amplified using the primers cyt $b$ : L14725 (5'-GTG ACT TGA AAA ACC ACC GTT G-3')

153 (Song et al., 1998) and H15573 (5'-AAT AGG AAG TAT CAT TCG GGT TTG ATG-3')

154 (Taberlet et al., 1992); and COI: FishF2 (5'-TCG ACT AAT CAT AAA GAT ATC GGC AC-

155 3') and FishR2 (5'-ACT TCA GGG TGA CCG AAG AAT CAG AA-3') (Ward et al., 2005).

156 The annealing temperatures of cyt $b$ and $C O I$ were $47^{\circ} \mathrm{C}$ and $50{ }^{\circ} \mathrm{C}$, respectively. The thermal

157 profiles of PCR were $94^{\circ} \mathrm{C}$ for $5 \mathrm{~min}$, followed by 37 cycles of $94{ }^{\circ} \mathrm{C}$ for $1 \mathrm{~min}$, annealing

158 temperature for $45 \mathrm{~s}$, and $72{ }^{\circ} \mathrm{C}$ for $1 \mathrm{~min}$, with a final extension at $72{ }^{\circ} \mathrm{C}$ for $10 \mathrm{~min}$. The quality 
159 of PCR products was checked by electrophoresis with $1.5 \%$ agarose gel and then purified using a

160 Macherey-Nagel purification kit (www.mn-net.com) according to the manufacturer's protocols.

161 DNA sequences were generated by an ABI 3730 automated sequencer at the Center for

162 Biotechnology, National Taiwan University. Sequences were assembled and edited manually and 163 aligned using MEGA version 6.0 (Tamura et al., 2013).

164 Sequences of cyt $b$ and $C O I$ were concatenated as a single genetic marker and the analyses

165 that followed were based on this data set. The genetic diversity indexes of haplotype diversity $(h)$

166 and nucleotide diversity $(\pi)$ were calculated in DnaSP version 5.0 (Librado \& Rozas, 2009)

167 according to Nei (1987). Pairwise $\Phi_{\mathrm{ST}}$ comparisons among sampling sites and among groups

168 with different classes of $\mathrm{T}_{\mathrm{GC}}$ were estimated in Arlequin version 3.5 (Excoffier \& Lischer, 2010),

169 and 10,000 permutations were used to estimate the departure from the null hypothesis of genetic

170 homogeneity. The statistical significance of pairwise $\Phi_{\mathrm{ST}}$ values was adjusted with Bonferroni

171 correction (Rice, 1989) for multiple comparisons. The hierarchical levels of genetic diversity

172 were tested through analysis of molecular variance (AMOVA; Excoffier et al., 1992), and the

173 proportions of variations among groups $\left(\Phi_{\mathrm{CT}}\right)$, among populations within groups $\left(\Phi_{\mathrm{SC}}\right)$, and

174 within populations $\left(\Phi_{\mathrm{ST}}\right)$ were calculated in Arlequin; 10,000 permutations were used to estimate

175 statistical significance. Two hypothetical grouping treatments were used for AMOVA: (1) based

176 on the three different latitudinal groups of Ishigaki, Taiwan, and Badian; and (2) based on the

177 sampling sites that were associated with three different ocean current conditions, namely the

178 Kuroshio Current system (Ishigaki, Shitiping, Jihui, and Green Island), mixed effect by

179 numerous water masses (Checheng, Wanlitong, and Liuqiu), and the interior current systems of

180 the Philippine archipelago (Badian). The minimum spanning network (MSN) of haplotypes was

181 built using Arlequin version 3.5 and HapStar version 0.7 (Teacher \& Griffiths, 2011) to connect

182 haplotypes based on the minimum differences between sequences. 


\section{OTOLITH MICROSTRUCTURE AND MICROCHEMISTRY}

185

186

187

188

189

190

191

192

193

194

195

196

197

198

199

200

201

202

203

204

205

The otolith microstructure of $U$. micropterus was similar to those of other marine eels (Ling et al., 2005; Correia et al., 2004; Lee et al., 2008). After polishing, the otolith core became a hole surrounded by a thick ring, referred to as a hatch check (HC; Fig. 2). The first feeding check (FFC) was assumed to form when yolks were absorbed completely and the leptocephali began to ingest external food. There were three to five blurry increments between $\mathrm{HC}$ and FFC in some individuals. The increments beyond FFC were circular, and the increment widths gradually increased to a peak of $1.1-2.0 \mu \mathrm{m}$ at approximately the $10^{\text {th }}$ to $20^{\text {th }}$ increments, followed by a gradual decrease to a minimum of $0.5-0.9 \mu \mathrm{m}$. Then, the growth increment width abruptly increased to $1.5-4.0 \mu \mathrm{m}$ by three to 28 increments and formed a profound growth check (GC).

The growth increments after GC were wider $(5-15 \mu \mathrm{m})$, diffused, and radiative. $\mathrm{The} \mathrm{Sr} / \mathrm{Ca}$ ratios of 14 U. micropterus fluctuated between 3 and $16 \times 10^{-3}$ from the core to the GC, with no apparent pattern. The $\mathrm{Sr} / \mathrm{Ca}$ ratios then dropped rapidly, accompanied by the appearance of the GC in all but one individual (Fig. 3).

\section{GENETIC DATA}

One hundred and thirty-two haplotypes from 1,336 bp concatenated mtDNA sequences from 195 U. micropterus were identified (GenBank accession number MF190188-MF190364). In total, 179 polymorphic sites, 112 parsimony informative sites, and 67 singleton variable sites were found. Haplotype diversity $(h)$ and nucleotide diversity $(\pi)$ ranged from 0.9921 to 1 $($ average $=0.9938)$ and 0.0060 to $0.0073($ average $=0.0065)$, respectively $($ Table 1$)$. The minimum spanning network showed many unique haplotypes, with only 28 of the 132 haplotypes shared by more than one individual. These unique haplotypes were connected to the 
206 center haplotype that occurred in Ishigaki, Shitiping, Checheng, and Badian. The most common

207 haplotype consisted of seven individuals from all locations except Liuqiu and Wanlitong.

208 Closely related haplotypes consisted of individuals from distinct regions, revealing no obvious 209 geographic pattern (Fig. 4).

210 The pairwise $\Phi_{\mathrm{ST}}$ values among sampling sites ranged from -0.025 to 0.121 . Liuqiu

211 revealed low but significant genetic variations with all sampling sites except Green Island. Only

212 Liuqiu versus Checheng was statistically significant after the most conservative Bonferroni

213 correction (Table 2). All pairwise $\Phi_{\mathrm{ST}}$ values among groups with different classes of $\mathrm{T}_{\mathrm{GC}}$

214 remained low and insignificant (Table S1). The AMOVA results showed that over 99\% of

215 variations occurred at the population level under both groupings. Only the $\Phi_{\mathrm{SC}}$ of different ocean

216 current conditions revealed low but statistically significant structure $\left(\Phi_{\mathrm{SC}}=0.017, P<0.05\right)$

217 (Table 3). The results of genetic analysis support the conclusion that $U$. micropterus in the study

218 areas should be considered genetically homogeneous with weak genetic structure.

219 PELAGIC LARVAL DURATION AND GROWTH RATE

220 The pelagic larval duration represented by the $\mathrm{T}_{\mathrm{GC}}$ ranged from 33 to 98 days for the eels

221 examined (Table 4). The maximum $\mathrm{T}_{\mathrm{GC}}$ of 98 days occurred in Liuqiu and the minimum of 33

222 days occurred in Badian. Liuqiu specimens had the longest and most variable $\mathrm{T}_{\mathrm{GC}}$. Ishigaki and

223 Taiwanese specimens had significantly longer $\mathrm{T}_{\mathrm{GC}}$ than those from Badian (Tukey HSD, $P<$

224 0.01). The otolith growth rate from the first feeding ring to the $\mathrm{GC}$ represented by $\mathrm{G}_{\mathrm{GC}}$ ranged

225 from 0.91 to $2.40 \mu \mathrm{m} \mathrm{day}^{-1}$. The maximum $\mathrm{G}_{\mathrm{GC}}$ of $2.40 \mu \mathrm{m} \mathrm{day}^{-1}$ occurred in Badian and the

226 minimum value of $0.91 \mu \mathrm{m} \mathrm{day}^{-1}$ occurred in Jihui. Significantly lower $\mathrm{G}_{\mathrm{GC}}$ were observed in

227 Ishigaki and Taiwanese specimens compared with Badian (Tukey HSD, $P<0.01$ ).

228 The eels were divided into three latitudinal groups according to sampling site, namely

229 Ishigaki $(\mathrm{n}=14)$, Taiwan (Shitiping, Jihui, Green Island, Checheng, Wanlitong, and Liuqiu; $\mathrm{n}=$ 
230 141) and Badian $(n=39)$. The respective mean \pm SD daily age and otolith growth rate were 54.6 $231 \pm 7.7$ days with $1.28 \pm 0.16 \mu \mathrm{m} \mathrm{day}^{-1}, 54.6 \pm 9.3$ days with $1.35 \pm 0.18 \mu \mathrm{m}$ day $^{-1}$, and $43.9 \pm 4.9$

232 days with $1.60 \pm 0.19 \mu \mathrm{m}$ day $^{-1}$. Ishigaki specimens had the lowest growth rate, whereas the

233 Badian specimens had the highest growth rate and shortest mean $\mathrm{T}_{\mathrm{GC}}$ (Table 5, Fig. 5(a) \& 6).

234 There were no significant differences in $\mathrm{T}_{\mathrm{GC}}$ and $\mathrm{G}_{\mathrm{GC}}$ between the Ishigaki and Taiwanese

235 specimens (Tukey HSD, $P>0.05$ ), and both were significantly different from the Badian

236 specimens (Tukey HSD, $P<0.001)$. The percentage of $\mathrm{T}_{\mathrm{GC}}$ peaked at $56-60$ days $(29 \%)$ in the

237 Ishigaki specimens, 46-50 days (24\%) in the Taiwanese specimens, and 41-45 days (44\%) in the

238 Badian specimens [Fig. 5(a)]. Uropterygius micropterus tended to have longer $\mathrm{T}_{\mathrm{GC}}$ and lower

$239 \mathrm{G}_{\mathrm{GC}}$ at higher latitudes.

240 The Taiwanese specimens were further divided into eastern (Shitiping, Jihui, and Green

241 Island; $\mathrm{n}=87$ ) and southwestern groups (Checheng, Wanlitong, and Liuqiu; $\mathrm{n}=54$ ), which had

242 mean \pm SD days and otolith growth rates of $52.6 \pm 8.0$ days $\left(1.36 \pm 0.16 \mu \mathrm{m}\right.$ day $\left.^{-1}\right)$ and $57.9 \pm$

24310.5 days $\left(1.33 \pm 0.19 \mu \mathrm{m} \mathrm{day}^{-1}\right)$, respectively. The specimens collected in southwestern Taiwan

244 had significantly longer $\mathrm{T}_{\mathrm{GC}}$ than those collected in eastern Taiwan (Tukey HSD, $P<0.01$ ),

245 whereas there was no significant difference in $\mathrm{G}_{\mathrm{GC}}$ (Tukey HSD, $P>0.05$ ) (Table 6). The

246 percentage of $\mathrm{T}_{\mathrm{GC}}$ peaked at 46-50 days (30\%) for the eastern Taiwan group and 51-55 days

247 (22\%) for the southwestern Taiwan group [Fig. 5(b)]. Uropterygius micropterus from

248 southwestern Taiwan had longer $\mathrm{T}_{\mathrm{GC}}$.

\section{DISCUSSION}

250

\section{EARLY LIFE HISTORY TRAITS}

251 The diameters of fertilized eggs and total lengths of newly hatched preleptocephalus larvae 252 of U. micropterus were 3.0-3.5 and $10.0 \mathrm{~mm}$ (Chen, H.M., unpublished data). The total lengths 
253 of U. micropterus leptocephali are approximately $60.0 \mathrm{~mm}$ at metamorphosis, based on

254 observations of two Uropterygius spp. in the early metamorphosis stage with total lengths of

25551.1 and $56.5 \mathrm{~mm}$ (Okiyama, 2014). Therefore, the larval growth rates of U. micropterus with

256 PLD of 33-98 days are likely to be between 0.5 and $1.5 \mathrm{~mm} \mathrm{day}^{-1}$. This fast larval growth rate

257 greater than $1 \mathrm{~mm}^{-1 a y^{-1}}$ was also observed in four other eel species in the eastern Gulf of

258 Mexico (Gymnothorax saxicola, Ophichthus gomesii, Ariosoma balearicum, and Paraconger

259 caudilimbatus) (Bishop et al., 2000).

260 In the present study, the commencement of leptocephalus metamorphosis was defined by

261 the $\mathrm{GC}$ where the $\mathrm{Sr} / \mathrm{Ca}$ ratio drastically decreased and the otolith growth increment widths

262 abruptly increased, similar to findings in other muraenids and eel species (Marui et al., 2001;

263 Correia et al., 2004; Ling et al., 2005). Although the biological meaning of GC remains unclear,

264 the first growth increment for this check should contain most of the leptocphalus stage and

265 sufficiently represent the PLD of U. micropterus among sampling locations.

266 Insignificant pairwise $\Phi_{\mathrm{ST}}$ values among groups with different PLDs (Table S1) indicate

267 that the plasticity of the PLD is likely due to individual acclimatization rather than different

268 genotypes. Although PLD variation can be explained by the different growth conditions or

269 birthplaces of the larvae, clearly characteristic PLDs were still observed among the groups in this

270 study, indicating that regional environmental factors may influence tendencies in early life

271 history traits (Searcy \& Sponaugle, 2000; Sponaugle \& Pinkard, 2004; Bay et al., 2006). Leis et

272 al. (2013) suggested three general classes of factors that might lead to differences in larval

273 dispersal, including biological (e.g. spawning mode and PLD), physical (water movement and

274 habitat fragmentation) and biophysical differences (principally temperature). In this study, $U$.

275 micropterus at relatively higher latitudes tend to have lower otolith growth rates and longer

276 PLDs compared with specimens at lower latitudes, potentially owing to water temperature. The 
277 sea surface temperatures (SSTs) during the spawning season and pelagic leptocephalus stage of

278 U. micropterus (Chen, 1997) were derived from Global Sea Temperature

279 (http://www.seatemperature.org/) (Fig. S1). The SST of Itoman (Japan) is $5{ }^{\circ} \mathrm{C}$ lower than that of 280 Guihulngan (the Philippines) in May and December, indicating that the leptocephali in the 281 different study areas experienced different SSTs regardless of whether the eels were self282 recruited or transported from other habitats. The effects of temperature on larval development 283 were discussed in rearing experiments that demonstrated positive correlations in Anguilla 284 japonica glass eels and elvers (Fukuda et al., 2009). Leptocephali at lower latitudes with higher 285 SSTs may grow faster and require less time to reach the minimum size for metamorphosis 286 (Reveillac et al., 2008). Because the latitude of Ishigaki is similar to that of eastern Taiwan, 287 neither the mean PLDs nor the otolith growth rates were expected to be different.

288 Since the effect of SST on larval growth can be excluded from the sampling sites in 289 Taiwanese waters, the relatively longer PLD in the southwestern specimens might be attributable 290 to different current systems or recruitment routes. Larval dispersal route is considered to be 291 strongly influenced by ocean currents (Kim et al., 2007). For instance, newly hatched larvae of 292 Conger myriaster can be retained in mesoscale eddies for several months, resulting in longer 293 PLD than expected (Kurogi et al., 2012). The strong Kuroshio Current flows northward along 294 the east coast of Taiwan year-round (Rudnick et al., 2011). When leptocephali competent to 295 metamorphose drift to this area, they can instantly metamorphose and settle. However, the 296 current system in southwestern Taiwan is affected by different water masses seasonally, 297 including the intrusion of the Kuroshio branch, the substitution of South China Sea surface water 298 mass into the Taiwan Strait, and other transient oceanographic events (Shaw, 1991; Farris \& 299 Wimbush, 1996; Hu et al., 2010). In addition, a weak anticyclonic eddy with a diameter of 100$300200 \mathrm{~km}$ was identified in this area (Fig. 1, Fig. S2). The leptocephali might entrain in the 
301 anticyclonic eddy or complicated current system and therefore require a longer time to settle

302 along the southwest coast of Taiwan.

303 POPULATION STRUCTURE AND LARVAL DISPERSAL

304 Previous studies have shown that the dispersal or retention of larvae may greatly influence 305 gene flow for demersal fishes (Taylor \& Hellberg, 2003). During the field collection stage, we

306 found that $U$. micropterus inhabited shallow water close to the upper tidal zone, which was

307 usually shallower than $1 \mathrm{~m}$ and was exposed to air during low tide. These habitats are usually

308 fragmented, but each has an extremely high density of individuals, suggesting that some larvae

309 hatched in the upper tidal zone may remain in nearshore areas and contribute to local habitats.

310 However, the fast-flowing Kuroshio Current is frequently used by the larvae of many eel species

311 for transportation to a wide range of areas (Miller et al., 2002), which may facilitate $U$.

312 micropterus gene flow. The sampling site at Badian is relatively isolated from the main oceanic

313 current systems around the Philippine archipelago. Compared with the Taiwanese sites in this

314 study, there may be fewer U. micropterus leptocephali drifting away from Badian per generation.

315 It is likely that a handful of migrants have sufficiently contributed to the genetic homogenization

316 among the study regions over timescales of tens to hundreds of thousands of years (Reece et al.,

317 2010).

318 Nevertheless, it seems that limited larval exchange over time is inadequate to explain the

319 significant genetic divergence of Liuqiu from all locations but Checheng with $\Phi_{\mathrm{ST}}$ before

320 Bonferroni correction. Unknown environmental mechanisms that restrict larval dispersal and

321 enhance massive self-recruitment may be a possible explanation. Previous studies have

322 suggested that the self-recruitment of larvae is a common phenomenon for marine fishes and

323 invertebrates, disregarding larval dispersal capabilities (Taylor \& Hellberg, 2003; Teske et al.,

324 2015). Self-recruitment of leptocephali is also surmised more often than dispersal in some areas 
325 and is attributed to local current systems, semi-enclosed ocean environments, or the swimming

326 ability of the larvae (Miller et al., 2011; Miller et al., 2016). Furthermore, the PLD of Liuqiu

327 specimens was the longest and most variable (46 to 98 days) of all sampling sites, indicating that

328 U. micropterus larvae had more complicated composition and different transportation routes to

329 Liuqiu. The longer PLD implies that some larvae might recruit from places with cooler water or

330 remote populations not included in this study. Further studies with larger-scale sampling among

331 a range of habitats may provide more details on the population genetic structure of $U$.

332 micropterus.

In the present study, intraspecific variations in PLD were found in U. micropterus among defined groups without obvious population genetic structure. These variations were likely acclimatization-dependent rather than genotype-dependent. Weak divergence of $U$. micropterus was observed in Liuqiu, southwestern Taiwan, most likely owing to the different recruiting routes of the leptocephali. This study suggests that the intraspecific variation in the PLDs of the eels might have resulted from different seawater temperatures and complex ocean conditions.

\section{ACKNOWLEDGEMENTS}

342 We are grateful to Dr. Yuichi Kano, Florence Evacitas, Jiunn-Shiun Chiou, Ming-Tai Chou,

343 Ying-Ching Yuan, Li-Chi Cheng, Yun-Ting Hsieh, Zen-Wei Lin, Kai-Chiang Chang, Po-Wei

344 Huang, Yu-Wei Liu, Chu-Feng Lu and Chang-Chun Liu for their assistance in specimen

345 collection; Dr. Hong-Ming Chen for providing reproductive information on the eels; and Sih-Yu

346 Chen, Han-Ting Huang, and Jhen Hsu for assistance in map drawing. We specially thank Joel

347 Corush and Margaret Scholten for assistance in English editing. 


\section{References}

349 Abràmoff MD, Magalhães PJ, Ram SJ. 2004. Image processing with ImageJ. Biophotonics $350 \quad$ International 11:36-42.

351 Bassett D, Montgomery J. 2011. Home range use and movement patterns of the yellow moray 352 eel Gymnothorax prasinus. Journal of Fish Biology 79:520-525. DOI: 10.1111/j.1095$353 \quad$ 8649.2011.03018.x.

354 Bay LK, Buechler K, Gagliano M, Caley MJ. 2006. Intraspecific variation in the pelagic larval 355 duration of tropical reef fishes. Journal of Fish Biology 68:1206-1214. DOI: 10.1111/j.0022-1112.2006.01016.x.

357

358

359

360

361

362 363

364

365

366

367

368

369

370

Bergenius MAJ, McCormick MI, Meekan MG, Robertson DR. 2005. Environmental influences on larval duration, growth and magnitude of settlement of a coral reef fish. Marine Biology 147:291-300. DOI: 10.1007/s00227-005-1575-z.

Bishop RE, Torres JJ, Crabtree RE. 2000. Chemical composition and growth indices in leptocephalus larvae. Marine Biology 137:205-214. DOI: 10.1007/s002270000362.

Bowen BW, Bass AL, Muss A, Carlin J, Robertson DR. 2006. Phylogeography of two Atlantic squirrelfishes (Family Holocentridae): exploring links between pelagic larval duration and population connectivity. Marine Biology 149:899-913. DOI: 10.1007/s00227-006-0252-1.

Bowen BW, Bass AL, Rocha LA, Grant WS, Robertson DR. 2001. Phylogeography of the trumpetfishes (Aulostomus): ring species complex on a global scale. Evolution 55:10291039. DOI: $10.1111 / \mathrm{j} .0014-3820.2001 . t b 00619 . x$.

Chen HM. 1997. Systematic Studies on the Muraenid Fishes (Muraenidae) from the Waters Around Taiwan. D. Phil. Thesis, National Taiwan Ocean University.

Correia AT, Able KW, Antunes C, COImbra J. 2004. Early life history of the American conger 
371

372

373

374 Correia AT, Ramos AA, Barros F, Silva G, Hamer P, Morais P, Cunha RL, Castilho R. 2012.

375 Population structure and connectivity of the European conger eel (Conger conger) across

376

377

378

379

380

381

382

383

384

385

eel (Conger oceanicus) as revealed by otolith microstructure and microchemistry of metamorphosing leptocephali. Marine Biology 145:477-488. DOI: 10.1007/s00227-0041349-z. the north-eastern Atlantic and western Mediterranean: integrating molecular and otolith elemental approaches. Marine biology 159:1509-1525. DOI: 10.1007/s00227-012-1936-3.

Excoffier L, Lischer HE. 2010. Arlequin suite ver 3.5: a new series of programs to perform population genetics analyses under Linux and Windows. Molecular Ecology Resources 10:564-567. DOI: 10.1111/j.1755-0998.2010.02847.x.

Excoffier L, Smouse PE, Quattro JM. 1992. Analysis of molecular variance inferred from metric distances among DNA haplotypes: application to human mitochondrial DNA restriction data. Genetics 131:479-491.

Farris A, Wimbush M. 1996. Wind-induced Kuroshio intrusion into the South China Sea. Journal of Oceanography 52:771-784. DOI: 10.1007/BF02239465.

Faurby S, Barber PH. 2012. Theoretical limits to the correlation between pelagic larval duration and population genetic structure. Molecular Ecology 21:3419-3432. DOI: 10.1111/j.1365294X.2012.05609.x.

Froese, R. \& Pauly, D. (2016). FishBase: World Wide Web electronic publication. Available at www.fishbase.org (accessed june 2016).

Fukuda N, Kuroki M, Shinoda A, Yamada Y, Okamura A, Aoyama J, Tsukamoto K. 2009. Influence of water temperature and feeding regime on otolith growth in Anguilla japonica glass eels and elvers: does otolith growth cease at low temperatures? Journal of Fish Biology 74:1915-1933. DOI: 10.1111/j.1095-8649.2009.02287.x. 
395 Han YS, Hung CL, Iizuka Y, Chang HC, Chang BJ, Ho HC, Shiao JC. 2010. Does larval 396 duration contribute to population genetic isolation of the Japanese eel Anguilla japonica? Fisheries Management and Ecology 17:366-368. DOI: 10.1111/j.1365-2400.2009.00729.x.

Hu J, Kawamura H, Li C, Hong H, Jiang Y. 2010. Review on current and seawater volume transport through the Taiwan Strait. Journal of Oceanography 66:591-610. DOI: 10.1007/s10872-010-0049-1.

Kim H, Kimura S, Shinoda A, Kitagawa T, Sasai Y, Sasaki H. 2007. Effect of El Niño on migration and larval transport of the Japanese eel (Anguilla japonica). ICES Journal of Marine Science 64:1387-1395. DOI: 10.1093/icesjms/fsm091.

Kimura Y, Ishikawa S, Tokai T, Nishida M, Tsukamoto K. 2004. Early life history characteristics and genetic homogeneity of Conger myriaster leptocephali along the east coast of central Japan. Fisheries Research 70:61-69. DOI: 10.1016/j.fishres.2004.06.015.

Kurogi H, Mochioka N, Okazaki M, Takahashi M, Miller MJ, Tsukamoto K, Ambe D, Katayama S, Chow S. 2012. Discovery of a spawning area of the common Japanese conger Conger myriaster along the Kyushu-Palau Ridge in the western North Pacific. Fisheries Science 78:525-532. DOI: 10.1007/s 12562-012-0468-6.

Kuroki M, Aoyama J, Miller MJ, Yoshinaga T, Shinoda A, Hagihara S, Tsukamoto K. 2009. Sympatric spawning of Anguilla marmorata and Anguilla japonica in the western North Pacific Ocean. Journal of Fish Biology 74:1853-1865. DOI: 10.1111/j.10958649.2009.02299.x.

Lee TW, Miller MJ, Hwang HB, Wouthuyzen S, Tsukamoto K. 2008. Distribution and early life history of Kaupichthys leptocephali (family Chlopsidae) in the central Indonesian Seas. Marine Biology 153:285-295. DOI: 10.1007/s00227-007-0804-z. 
Shanks AL, Sogard SM, Swearer SE, Treml EA, Vetter RD, Warner RR. 2013. Does fish

420 larval dispersal differ between high and low latitudes? Proceedings of the Royal Society of

421 London. Series B, Biological Sciences 280:20130327. DOI: 10.1098/rspb.2013.0327

422 Librado P, Rozas J. 2009. DnaSP v5: a software for comprehensive analysis of DNA 423 polymorphism data. Bioinformatics 25:1451-1452. DOI: 10.1093/bioinformatics/btp187.

424 Ling YJ, Iizuka Y, Tzeng WN. 2005. Decreased Sr/Ca ratios in the otoliths of two marine eels, 425 Gymnothorax reticularis and Muraenesox cinereus, during metamorphosis. Marine Ecology 426 Progress Series 304:201-206. DOI: 10.3354/meps304201.

427 Loh KH, Shao KT, Chen HM. 2011. Length-weight relationships for 39 species of moray eel 428 from the waters around Taiwan. Journal of Applied Ichthyology 27:945-948. DOI:

$429 \quad 10.1111 / \mathrm{j} .1439-0426.2010 .01601 . x$.

Macpherson E, Raventos N. 2006. Relationship between pelagic larval duration and geographic distribution of Mediterranean littoral fishes. Marine Ecology Progress Series 327:257-265.

Marui M, Arai T, Miller MJ, Jellyman DJ, Tsukamoto K. 2001. Comparison of early life history between New Zealand temperate eels and Pacific tropical eels revealed by otolith microstructure and microchemistry. Marine Ecology Progress Series 213:273-284. DOI:10.3354/meps213273.

Miller MJ, McCleave JD. 2007. Species assemblages of leptocephali in the southwestern Sargasso Sea. Marine Ecology Progress Series 344:197-212. DOI: 10.3354/meps06923. the Kuroshio current and East China Sea. Marine Ecology Progress Series 235:279-288. DOI: $10.3354 / \operatorname{meps} 235279$.

442 Miller MJ, Wouthuyzen S, Ma T, Aoyama J, Suharti SR, Minegishi Y, Tsukamoto K. 2011. 
443 Distribution, diversity, and abundance of garden eel larvae off West Sumatra,

$444 \quad$ Indonesia. Zoological Studies 50:177-191.

445 Miller MJ, Wouthuyzen S, Sugeha HY, Kuroki M, Tawa A, Watanabe S, Syahailatua A, Suharti

446 S, Tantu FY, Otake T, Tsukamoto K, Aoyama J. 2016. High biodiversity of leptocephali in

447 Tomini Bay Indonesia in the center of the Coral Triangle. Regional Studies in Marine

$448 \quad$ Science 8:99-113. DOI: 10.1016/j.rsma.2016.09.006.

449 Moyer JT, Zaiser MJ. 1982. Reproductive behavior of moray eels at Miyake-jima,

450 Japan. Japanese Journal of Ichthyology 28:466-468. DOI: 10.11369/jji1950.28.466.

451 Nanninga GB, Saenz-Agudelo P, Manica A, Berumen ML. 2014. Environmental gradients

452 predict the genetic population structure of a coral reef fish in the Red Sea. Molecular

453 Ecology 23:591-602. DOI: 10.1111/mec.12623.

454 Nei M. 1987. Molecular Evolutionary Genetics. New York: Columbia university press.

455 Okiyama M. 2014. An atlas of early stage fishes in Japan: second edition. Tokyo: Tokai

$456 \quad$ University Press.

457 R Development Core Team (2013). R: a language and environment for statistical computing. R

458 Foundation for Statistical Computing, Vienna. Available at https://cran.r-project.org/.

459 Reece JS, Bowen BW, Joshi K, Goz V, Larson A. 2010. Phylogeography of two moray eels

460 indicates high dispersal throughout the Indo-Pacific. Journal of Heredity 102:1-12. DOI:

$461 \quad$ 10.1093/jhered/esq036.

462 Reece JS, Bowen BW, Smith DG, Larson A. 2011. Comparative phylogeography of four Indo-

463 Pacific moray eel species (Muraenidae) reveals comparable ocean-wide genetic

464 connectivity despite five-fold differences in available adult habitat. Marine Ecology

465 Progress Series 437:269-277. DOI: 10.3354/meps09248.

466 Reveillac E, Feunteun E, Berrebi P, Gagnaire PA, Lecomte-Finiger R, Bosc P, Robinet T. 2008. 
467

468

469

470

471

472

473

474

475

476

477

478

479

480

481

482

483

484

485

486

487

488

489

490

Anguilla marmorata larval migration plasticity as revealed by otolith microstructural analysis. Canadian Journal of Fisheries and Aquatic Sciences 65:2127-2137. DOI: 10.1139/F08-122.

Rice WR. 1989. Analyzing tables of statistical tests. Evolution 43:223-225. DOI: $10.2307 / 2409177$

Rudnick DL, Jan S, Centurioni L, Lee CM, Lien RC, Wang J, Lee DK, Tseng RS, Kim YY, Chern CS. 2011. Seasonal and mesoscale variability of the Kuroshio near its origin. Oceanography 24:52-63. DOI: 10.5670/oceanog.2011.94.

Searcy SP, Sponaugle S. 2000. Variable larval growth in a coral reef fish. Marine Ecology Progress Series 206:213-226. DOI: 10.3354/meps206213.

Shaw PT. 1991. The seasonal variation of the intrusion of the Philippine Sea water into the South China Sea. Journal of Geophysical Research: Oceans 96:821-827. DOI:

$10.1029 / 90 J C 02367$.

Shinoda A, Tanaka H, Kagawa H, Ohta H, Tsukamoto K. 2004. Otolith microstructural analysis of reared larvae of the Japanese eel Anguilla japonica. Fisheries science 70:339-341. DOI:

10.1111/j.1444-2906.2003.00810.x.

Smith DG. 2012. A checklist of the moray eels of the world (Teleostei: Anguilliformes:

Muraenidae). Zootaxa 3474:1-64.

Song CB, Near TJ, Page LM. 1998. Phylogenetic relations among percid fishes as inferred from mitochondrial cytochrome b DNA sequence data. Molecular Phylogenetics and Evolution 10:343-353. DOI: 10.1006/mpev.1998.0542.

Sponaugle S, Pinkard DR. 2004. Impact of variable pelagic environments on natural larval growth and recruitment of the reef fish Thalassoma bifasciatum. Journal of Fish Biology 64:34-54. DOI: 10.1111/j.1095-8649.2004.00279.x. 
491 Sugeha HY, Shinoda A, Marui M, Arai T, Tsukamoto K. 2001. Validation of otolith daily

492 increments in the tropical eel Anguilla marmorata. Marine Ecology Progress Series

493 220:291-294. DOI: 10.3354/meps220291.

494 Taberlet P, Meyer A, Bouvet J. 1992. Unusually large mitochondrial variation in populations of

495 the blue tit, Parus caeruleus. Molecular Ecology 1:27-36. DOI: 10.1111/j.1365-

$496 \quad$ 294X.1992.tb00152.x.

497 Tamura K, Stecher G, Peterson D, Filipski A, Kumar S. 2013. MEGA6: molecular evolutionary

498 genetics analysis version 6.0. Molecular Biology and Evolution 30:2725-2729. DOI:

$499 \quad 10.1093 / \mathrm{molbev} / \mathrm{mst} 197$.

500 Taylor MS, Hellberg ME. 2003. Genetic evidence for local retention of pelagic larvae in a

501 Caribbean reef fish. Science 299:107-109. DOI: 10.1126/science.1079365.

502 Teacher AGF, Griffiths DJ. 2011. HapStar: automated haplotype network layout and

503 visualization. Molecular Ecology Resources 11:151-153. DOI: 10.1111/j.1755-

$504 \quad 0998.2010 .02890 . x$.

505 Teske PR, Sandoval-Castillo J, van Sebille E, Waters J, Beheregaray LB. 2015. On-shelf larval

506 retention limits population connectivity in a coastal broadcast spawner. Marine Ecology

507 Progress Series 532:1-12. DOI: 10.3354/meps11362.

508 Thresher RE, Colin PL, Bell LJ. 1989. Planktonic duration, distribution and population structure 509 of western and central Pacific damselfishes (Pomacentridae). Copeia 1989:420-434. DOI:

$510 \quad 10.2307 / 1445439$.

511 Tsukamoto K, Aoyama J, Miller MJ. 2002. Migration, speciation, and the evolution of diadromy

512 in anguillid eels. Canadian Journal of Fisheries and Aquatic Sciences 59:1989-1998. DOI:

$513 \quad 10.1139 / \mathrm{f02}-165$.

514 Tsukamoto K, Watanabe S, Kuroki M, Aoyama J, Miller MJ. 2014. Freshwater habitat use by a 
515 moray eel species, Gymnothorax polyuranodon, in Fiji shown by otolith microchemistry.

516 Environmental Biology of Fishes 97:1377-1385. DOI: 10.1007/s10641-014-0228-9.

517 Tsukamoto K. 2006. Oceanic biology: spawning of eels near a seamount. Nature 439:929-929.

$518 \quad$ DOI: $10.1038 / 439929 a$.

519 Ward RD, Zemlak TS, Innes BH, Last PR, Hebert PD. 2005. DNA barcoding Australia's fish

520 species. Philosophical Transactions of the Royal Society of London B: Biological Sciences

$521 \quad 360: 1847-1857$. DOI: 10.1098/rstb.2005.1716.

522 Weersing KA, Toonen RJ. 2009. Population genetics, larval dispersal, and demographic

523 connectivity in marine systems. Marine Ecology Progress Series 393:1-12. DOI:

$524 \quad 10.3354 /$ meps 08287. 


\section{Table $\mathbf{1}$ (on next page)}

Summary of collection data and sample size for the otoliths and mtDNA analysis of Uropterygius micropterus used in this study.

The number of alleles, variable sites (S), haplotype diversity ( $h$ ), and nucleotide diversity $(\pi)$. 


\begin{tabular}{cccccccccc}
\hline Country & Location & Code & $\mathrm{N}$ & $\mathrm{N}$ otolith & $\mathrm{N} \mathrm{mtDNA}$ & No. alleles & $\mathrm{S}$ & $h$ & $\pi$ \\
\hline \multirow{2}{*}{ Japan } & Ishigaki & $\mathrm{IG}$ & 14 & 14 & 14 & 14 & 44 & 1.0000 & 0.0063 \\
\cline { 3 - 9 } Taiwan & Shitiping & $\mathrm{ST}$ & 36 & 36 & 36 & 31 & 74 & 0.9921 & 0.0060 \\
& Jihui & $\mathrm{JH}$ & 32 & 31 & 32 & 31 & 88 & 0.9980 & 0.0073 \\
& Green Island & $\mathrm{GI}$ & 20 & 20 & 10 & 10 & 35 & 1.0000 & 0.0067 \\
& Checheng & $\mathrm{CC}$ & 31 & 31 & 31 & 30 & 73 & 0.9979 & 0.0061 \\
& Wanlitong & KT & 11 & 11 & 11 & 11 & 42 & 1.0000 & 0.0062 \\
& Liuqiu & LQ & 12 & 12 & 12 & 12 & 32 & 1.0000 & 0.0069 \\
\cline { 3 - 10 } & & Taiwan total & 142 & 141 & 132 & 99 & 157 & 0.9940 & 0.0066 \\
\cline { 3 - 10 } Philippines & Badian & BD & 39 & 39 & 39 & 37 & 85 & 0.9973 & 0.0064 \\
\hline & & All specimens & 195 & 194 & 185 & 132 & 179 & 0.9938 & 0.0065 \\
\hline
\end{tabular}




\section{Table 2 (on next page)}

Pairwise $\Phi_{\text {ST }}$ values between locations analyzed from the concatenated mtDNA sequence (1336 bp).

IG: Ishigaki, ST: Shitiping, JH: Jihui, GI: Green Island, CC: Checheng, KT: Wanlitong, LQ: Liuqiu, BD: Badian. ${ }^{*}<<0.05 ; * *<0.01 ;{ }^{* * * P}<0.001$. Bold, significant after Bonferroni correction. 


\begin{tabular}{|c|c|c|c|c|c|c|c|c|}
\hline & \multirow{2}{*}{$\begin{array}{l}\text { Japan } \\
\text { IG }\end{array}$} & \multicolumn{6}{|c|}{ Taiwan } & \multirow{2}{*}{$\begin{array}{l}\text { Philippines } \\
\text { BD }\end{array}$} \\
\hline & & $\mathrm{ST}$ & $\mathrm{JH}$ & GI & $\mathrm{CC}$ & KT & LQ & \\
\hline \multicolumn{9}{|l|}{ IG } \\
\hline ST & -0.015 & & & & & & & \\
\hline JH & -0.014 & -0.006 & & & & & & \\
\hline GI & 0.010 & -0.014 & -0.016 & & & & & \\
\hline $\mathrm{CC}$ & -0.009 & -0.004 & -0.004 & -0.005 & & & & \\
\hline KT & -0.009 & -0.011 & -0.016 & -0.009 & -0.020 & & & \\
\hline LQ & $0.089^{*}$ & $0.090^{* *}$ & $0.044^{*}$ & 0.065 & $0.116^{* * *}$ & $0.121^{* *}$ & & \\
\hline $\mathrm{BD}$ & -0.025 & -0.002 & -0.002 & 0.005 & -0.003 & -0.004 & $0.102^{* *}$ & \\
\hline
\end{tabular}




\section{Table 3 (on next page)}

AMOVA results for the concatenated mtDNA sequence (1336 bp) based on two hypothetical groupings.

IG: Ishigaki, ST: Shitiping, JH: Jihui, GI: Green Island, CC: Checheng, KT: Wanlitong, LQ: Liuqiu, BD: Badian. $* P<0.05$. 


\begin{tabular}{|c|c|c|c|c|}
\hline Source of variations & $\begin{array}{l}\text { Degree of } \\
\text { freedom }\end{array}$ & $\begin{array}{l}\text { Sum of } \\
\text { squares }\end{array}$ & $\begin{array}{c}\% \text { of } \\
\text { variation }\end{array}$ & $\begin{array}{l}\text { Fixation } \\
\text { index }\end{array}$ \\
\hline \multicolumn{5}{|c|}{ Three different latitudinal groups: Ishigaki (IG) vs. Taiwan (ST, JH, GI, CC, KT, LQ) } \\
\hline \multicolumn{5}{|c|}{ vs. Badian (BD) } \\
\hline Among groups & 2 & 8.4 & -0.97 & $-0.010\left(\Phi_{\mathrm{CT}}\right)$ \\
\hline $\begin{array}{c}\text { Among populations within } \\
\text { groups }\end{array}$ & 5 & 28.3 & 1.35 & $0.013\left(\Phi_{\mathrm{SC}}\right)$ \\
\hline Within populations & 177 & 781.3 & 99.61 & $0.004\left(\Phi_{\mathrm{ST}}\right)$ \\
\hline \multicolumn{5}{|c|}{ Three different ocean current conditions: (IG, ST, JH, GI) vs. (CC, KT, LQ) vs. (BD) } \\
\hline Among groups & 2 & 7.7 & -1.12 & $-0.011\left(\Phi_{\mathrm{CT}}\right)$ \\
\hline $\begin{array}{l}\text { Among populations within } \\
\text { groups }\end{array}$ & 5 & 29.1 & 1.67 & $0.017^{*}\left(\Phi_{\mathrm{SC}}\right)$ \\
\hline Within populations & 177 & 781.3 & 99.45 & $0.006\left(\Phi_{\mathrm{ST}}\right)$ \\
\hline
\end{tabular}

1 


\section{Table 4 (on next page)}

Detailed data on ranges, means, and statistical analyses of otolith growth rates and increments for all locations used in this study.

Otolith increments calculated from first feeding check (FFC) to growth check (GC) are represented as $T_{G C}$, and otolith growth rate is represented as $G_{G C}$. IG: Ishigaki, ST: Shitiping, JH: Jihui, GI: Green Island, CC: Checheng, KT: Wanlitong, LQ: Liuqiu, BD: Badian. ${ }^{* * * P}<0.001$ (ANOVA test). Numbers with the same superscript letters (i.e., a, b, ab) are not significantly different (Tukey HSD test, $P \geq 0.05$ ). 


\begin{tabular}{|c|c|c|c|c|c|c|c|c|c|}
\hline & & \multirow{2}{*}{$\begin{array}{c}\text { Ishigaki } \\
\text { IG }\end{array}$} & \multicolumn{6}{|c|}{ Taiwan } & \multirow{2}{*}{$\begin{array}{c}\text { Badian } \\
\text { BD }\end{array}$} \\
\hline & & & ST & $\mathrm{JH}$ & GI & $\mathrm{CC}$ & $\mathrm{KT}$ & LQ & \\
\hline $\mathrm{T}_{\mathrm{GC}}$ & Range & $41-68$ & $42-69$ & $39-69$ & $44-74$ & $40-85$ & $41-66$ & $46-98$ & $33-56$ \\
\hline (days) & Mean $^{* * *}$ & $54.6 \pm 7.7^{\mathrm{ab}}$ & $51.8 \pm 7.2^{b}$ & $51.7 \pm 7.9^{b}$ & $55.2 \pm 9.1^{\mathrm{ab}}$ & $57.6 \pm 9.7^{a b}$ & $55.2 \pm 6.9^{\mathrm{ab}}$ & $61.2 \pm 14.6^{\mathrm{a}}$ & $43.9 \pm 4.9^{c}$ \\
\hline $\mathrm{G}_{\mathrm{GC}}$ & Range & $1.04-1.55$ & $0.95-1.58$ & $0.91-1.87$ & $0.99-1.66$ & $0.93-1.73$ & $1.16-1.57$ & $0.98-1.79$ & $1.22-2.40$ \\
\hline \multirow[t]{2}{*}{$\left(\mu \mathrm{m}\right.$ day $\left.^{-1}\right)$} & Mean $^{* * *}$ & $1.28 \pm 0.16^{\mathrm{a}}$ & $1.36 \pm 0.14^{\mathrm{a}}$ & $1.39 \pm 0.17^{\mathrm{a}}$ & $1.32 \pm 0.18^{\mathrm{a}}$ & $1.31 \pm 0.21^{\mathrm{a}}$ & $1.33 \pm 0.11^{\mathrm{a}}$ & $1.38 \pm 0.22^{\mathrm{a}}$ & $1.60 \pm 0.19^{b}$ \\
\hline & $\mathrm{N}$ & 14 & 36 & 31 & 20 & 31 & 11 & 12 & 39 \\
\hline
\end{tabular}

1 


\section{Table 5 (on next page)}

Otolith increments and growth rates from first feeding check (FFC) to growth check (GC) based on three latitudinal groups.

IG: Ishigaki, ST: Shitiping, JH: Jihui, GI: Green Island, CC: Checheng, KT: Wanlitong, LQ: Liuqiu, BD: Badian. ${ }^{* * * P}<0.001$ (ANOVA test). Numbers with the same superscript letters (i.e., a, b) are not significantly different (Tukey HSD test, $P \geq 0.05$ ). 


\begin{tabular}{clccc}
\hline & & Ishigaki & Taiwan & Badian \\
& & $\mathrm{IG}$ & $\mathrm{ST}, \mathrm{JH}, \mathrm{GI}, \mathrm{CC}, \mathrm{KT}, \mathrm{LQ}$ & $\mathrm{BD}$ \\
\hline $\mathrm{T}_{\mathrm{GC}}$ & Range & $41-68$ & $39-98$ & $33-56$ \\
$($ days $)$ & Mean $^{* * *}$ & $54.6 \pm 7.7^{\mathrm{a}}$ & $54.6 \pm 9.3^{\mathrm{a}}$ & $43.9 \pm 4.9^{\mathrm{b}}$ \\
$\mathrm{G}_{\mathrm{GC}}$ & Range & $1.04-1.55$ & $0.91-1.87$ & $1.22-2.40$ \\
$\left(\mu \mathrm{m} \mathrm{day}^{-1}\right)$ & Mean $^{* * *}$ & $1.28 \pm 0.16^{\mathrm{a}}$ & $1.35 \pm 0.18^{\mathrm{a}}$ & $1.60 \pm 0.19^{\mathrm{b}}$ \\
\hline & $\mathrm{N}$ & 14 & 141 & 39 \\
\hline
\end{tabular}

1 


\section{Table 6(on next page)}

Otolith increments and growth rates from first feeding check (FFC) to growth check (GC).

Specimens from Taiwan are divided into eastern and southwestern groups to test the effect of different current conditions on early life history traits. IG: Ishigaki, ST: Shitiping, JH: Jihui, GI: Green Island, CC: Checheng, KT: Wanlitong, LQ: Liuqiu, BD: Badian. ***P $<0.001$ (ANOVA test). Numbers with the same superscript letters (i.e., a, b, ab) are not significantly different (Tukey HSD test, $P \geq 0.05$ ). 


\begin{tabular}{clcccc}
\hline & & Ishigaki & Southwestern Taiwan & Eastern Taiwan & Badian \\
& & IG & CC, KT, LQ & ST, JH, GI & BD \\
\hline $\mathrm{T}_{\mathrm{GC}}$ & Range & $41-68$ & $40-98$ & $39-74$ & $33-56$ \\
$($ days $)$ & Mean $^{* * *}$ & $54.6 \pm 7.7^{\mathrm{ab}}$ & $57.9 \pm 10.5^{\mathrm{a}}$ & $52.6 \pm 8.0^{\mathrm{b}}$ & $43.9 \pm 4.9^{\mathrm{c}}$ \\
$\mathrm{G}_{\mathrm{GC}}$ & Range $^{* *}$ & $1.04-1.55$ & $0.93-1.79$ & $0.91-1.87$ & $1.22-2.40$ \\
$\left(\mu \mathrm{m} \mathrm{day}^{-1}\right)$ & Mean $^{* * *}$ & $1.28 \pm 0.16^{\mathrm{a}}$ & $1.33 \pm 0.19^{\mathrm{a}}$ & $1.36 \pm 0.16^{\mathrm{a}}$ & $1.60 \pm 0.19^{\mathrm{b}}$ \\
\hline & $\mathrm{N}$ & 14 & 54 & 87 & 39 \\
\hline
\end{tabular}


Figure 1

Map of sampling sites for Uropterygius micropterus.

Within the pie charts, colors indicate the percentages of pelagic larval duration (PLD) for each sampling site. 


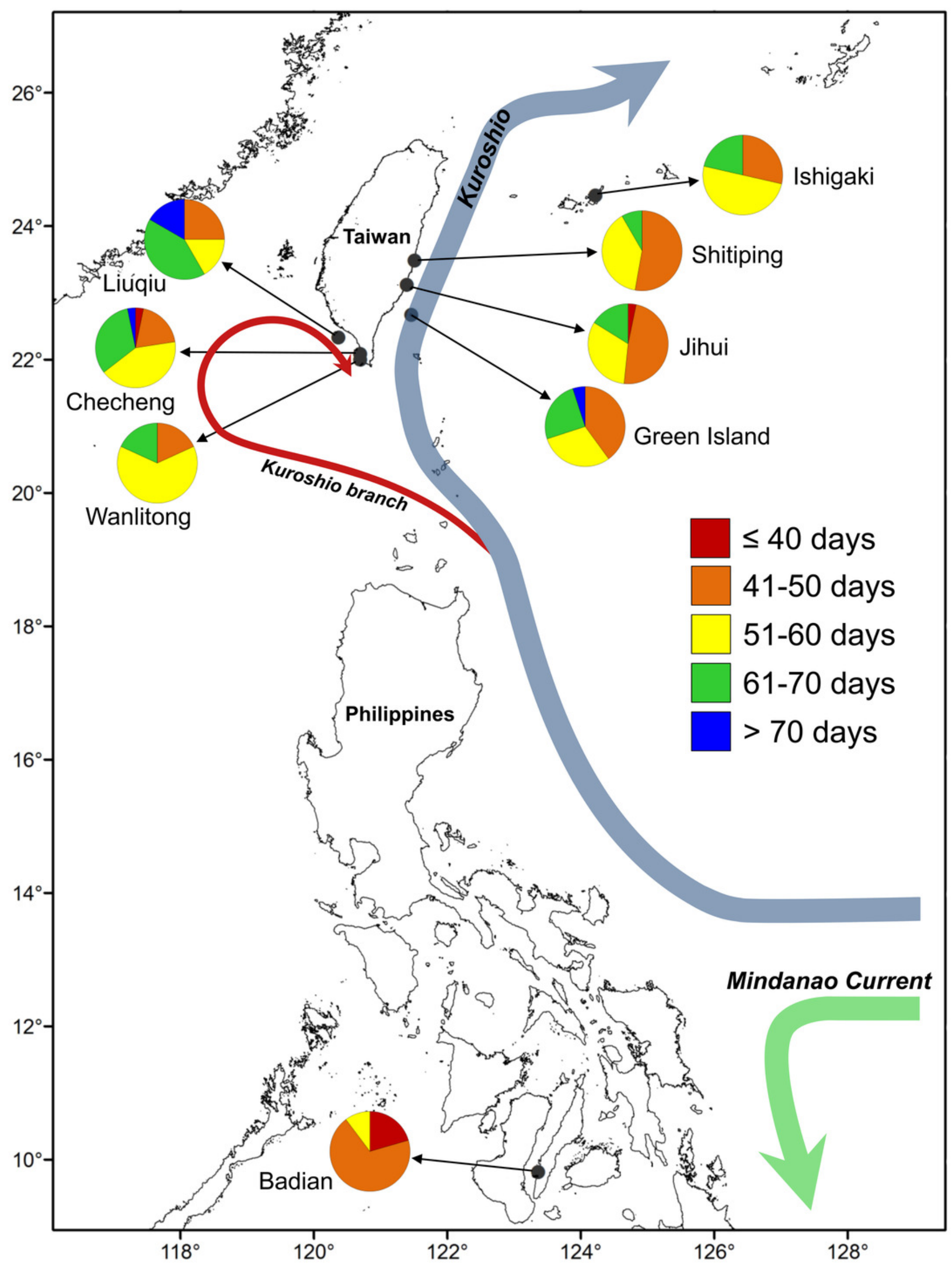




\section{Figure 2}

Otolith microstructure.

Otolith microstructure showing the hatch check (HC), first feeding check (FFC), and growth $\operatorname{check}(\mathrm{GC})$.

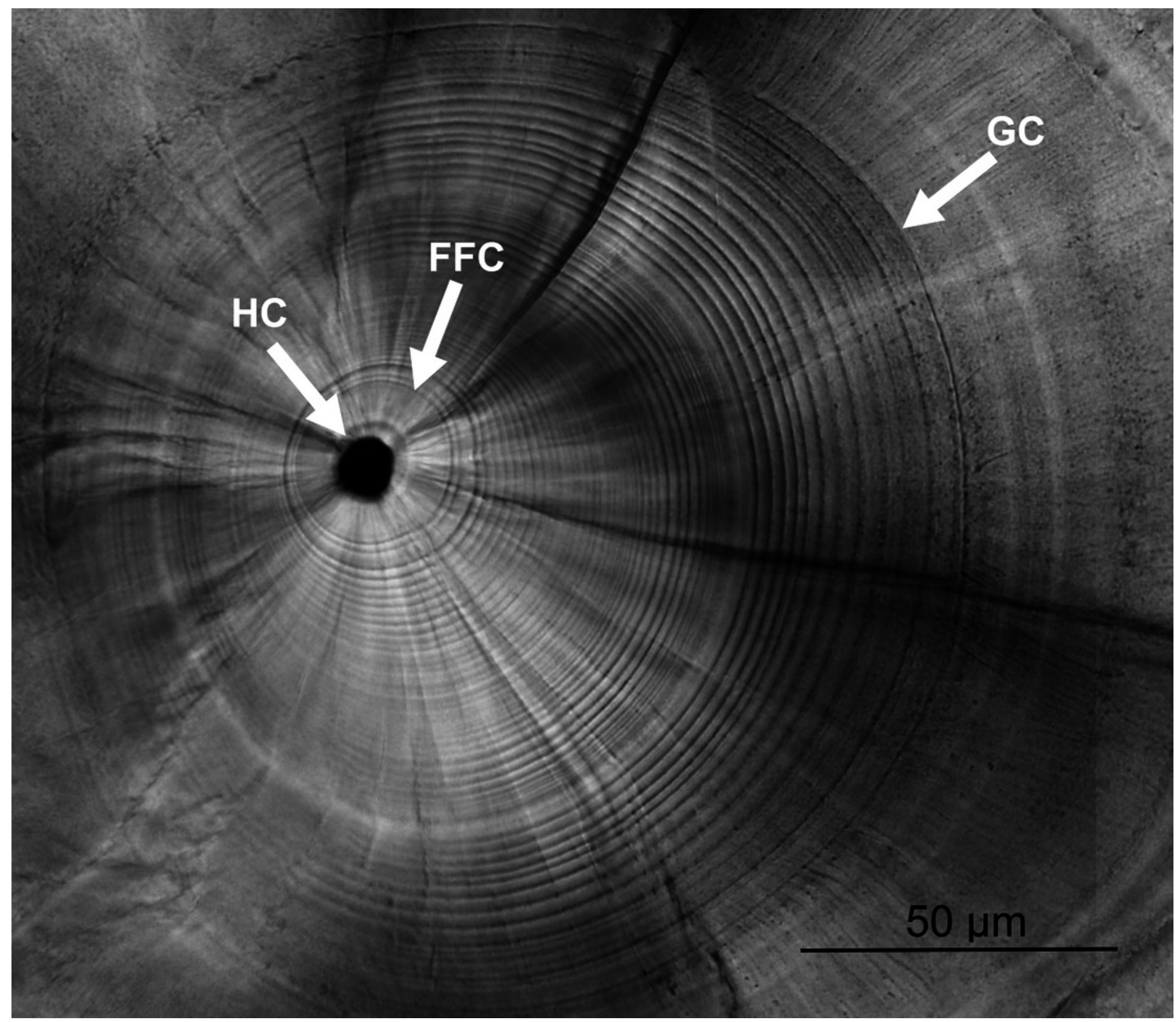


Figure 3

Patterns of otolith increment widths and Sr/Ca ratios from a Jihui specimen.

Arrows represent the position of the growth check (GC).

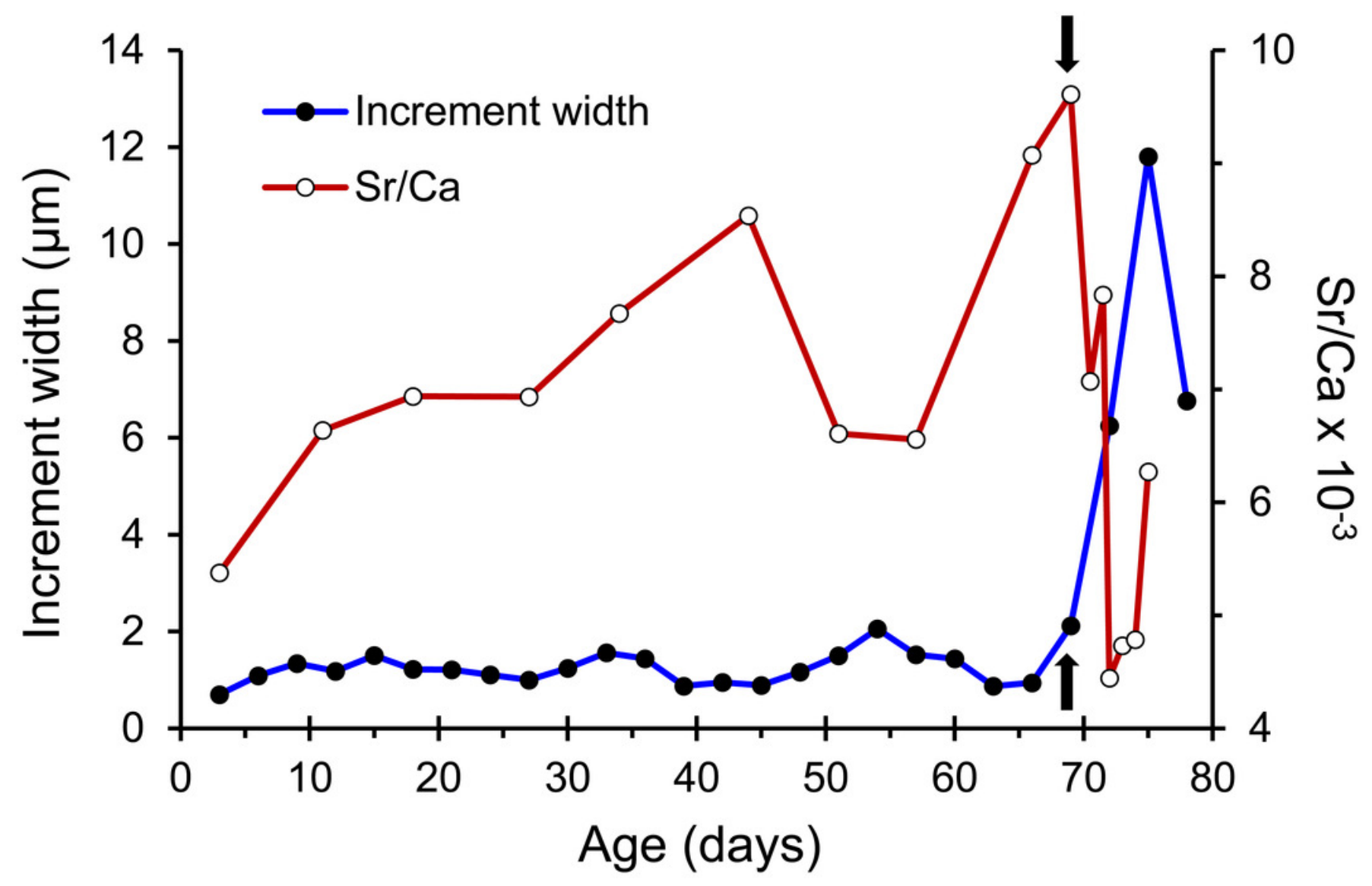




\section{Figure 4}

Minimum spanning network built from 185 concatenated mtDNA sequence (1336 bp) of Uropterygius micropterus with 132 haplotypes.

Colors represent correspondent sampling sites; the size of each pie chart is proportional to the number of individuals; hollow circles are haplotypes that were not collected in this study. 


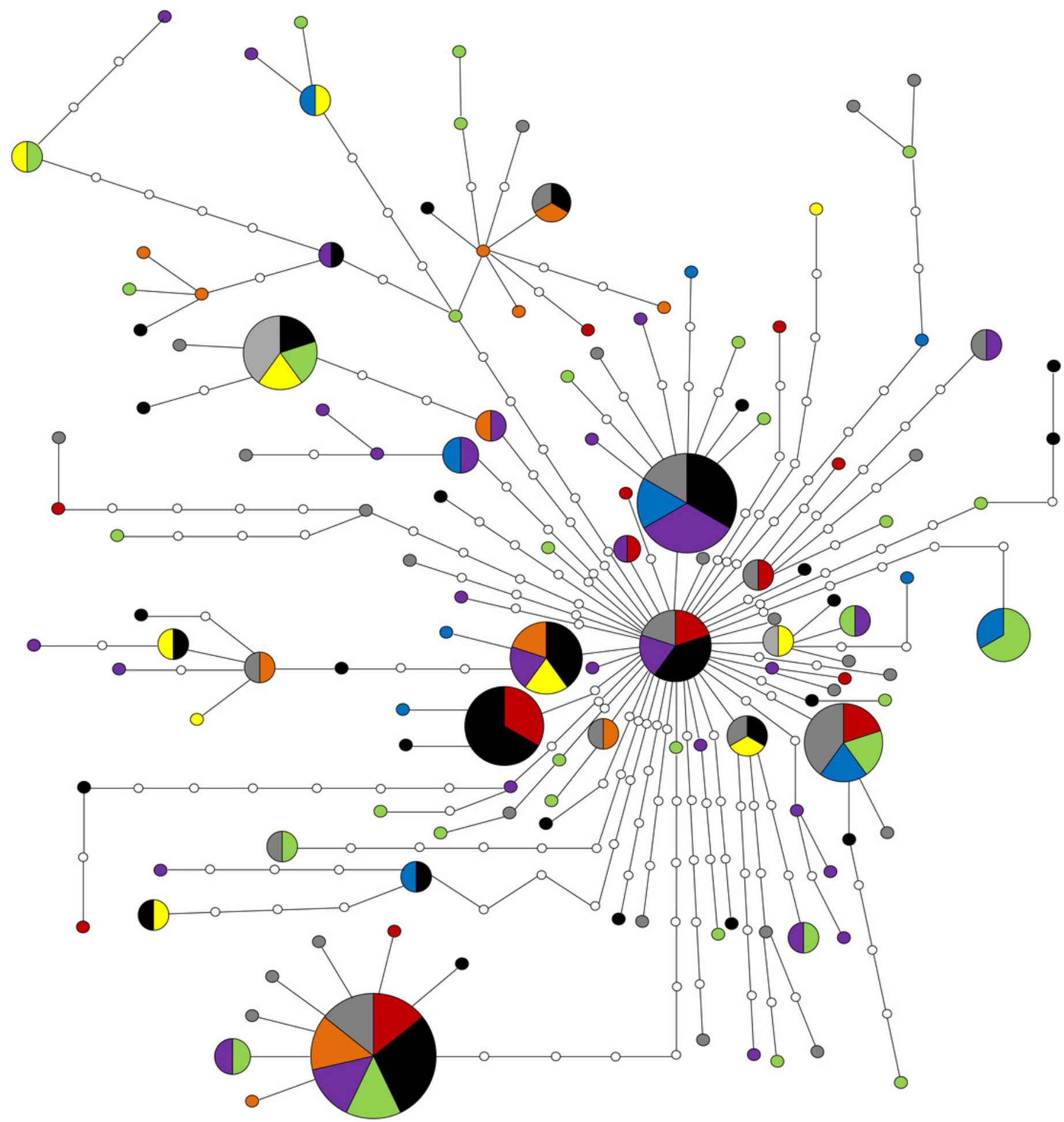
Ishigaki
- Shitiping
Jihui
Green Island
Checheng
Wanlitong
Liuqiu
Badian 


\section{Figure 5}

Frequency distributions of PLD.

Frequency distributions of PLD based on (a) Ishigaki $(n=14)$, Taiwan $(n=141)$, and Badian ( $n=39$ ) and (b) Eastern (Shitiping, Jihui, and Green Island, $n=87$ ) and Southwestern Taiwan (Checheng, Wanlitong, and Liuqiu, $\mathrm{n}=54$ ). 


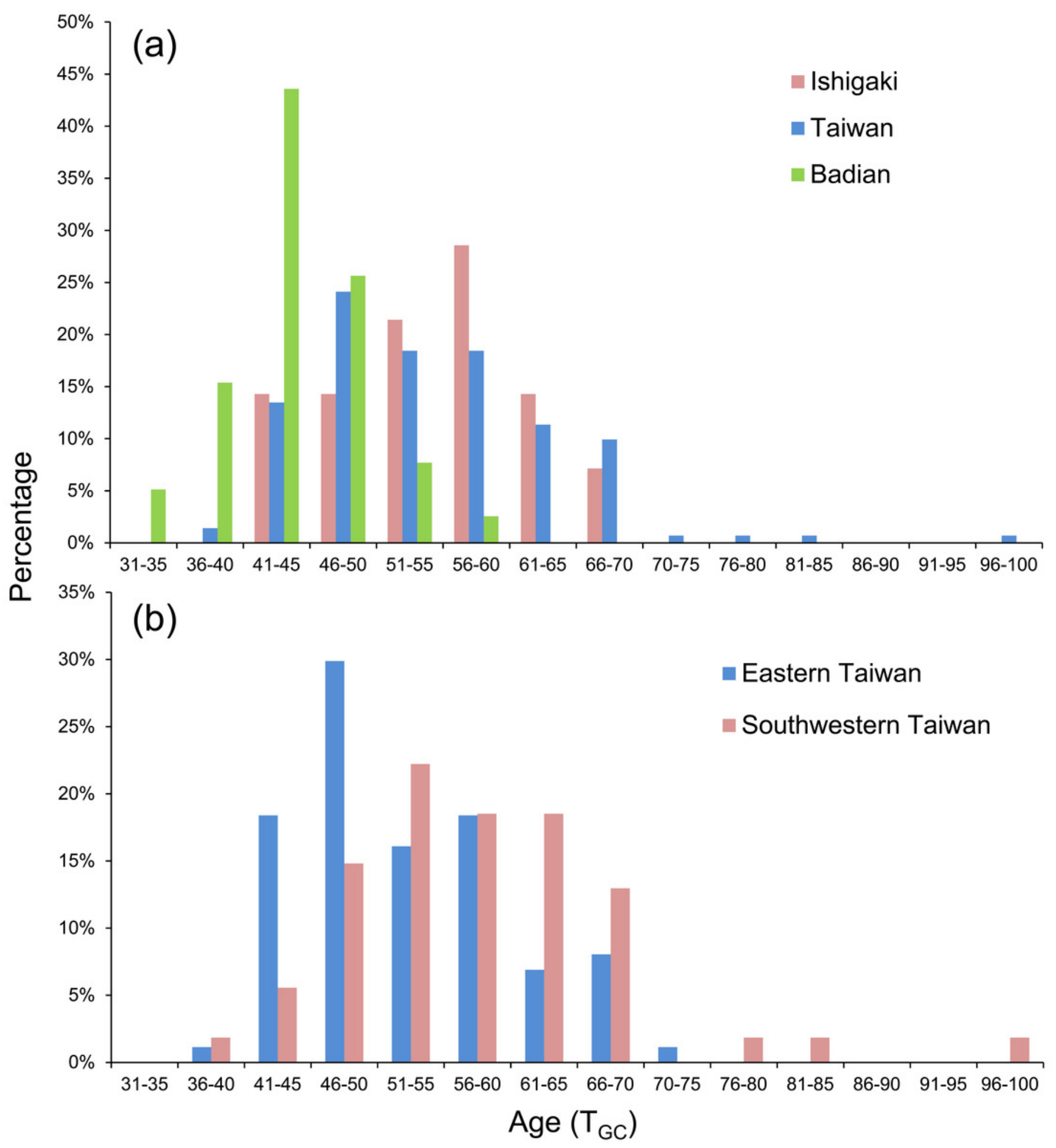


Figure 6

Sequential changes of increment widths from first feeding check (FFC) to growth check (GC) based on three latitudinal groups.

Ishigaki $(n=13)$, Taiwan $(n=126)$, and Badian $(n=37)$.

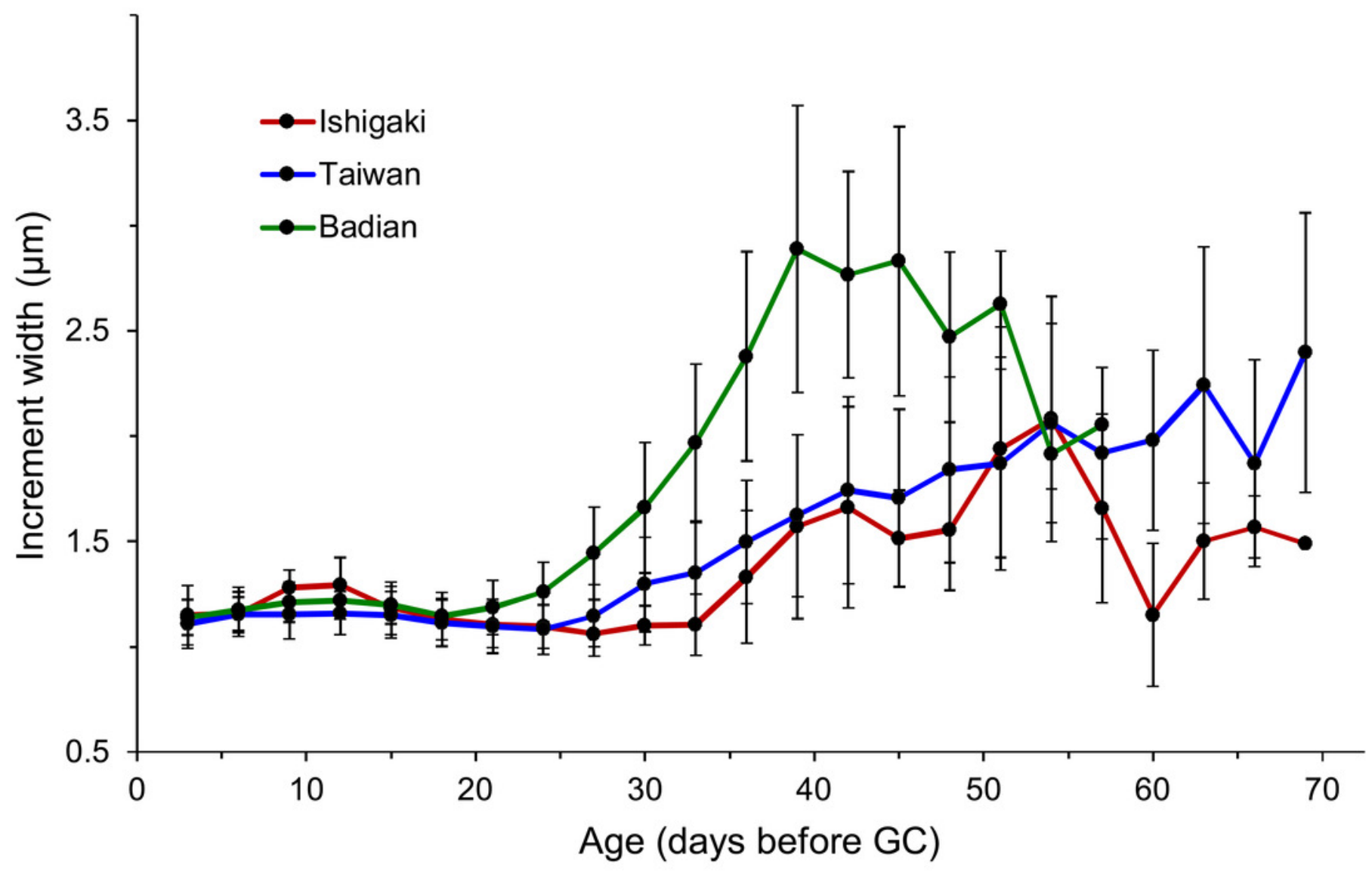

